\title{
Chemical and spectroscopic analysis of organic matter transformations during composting of pig manure
}

\author{
Jenn-Hung Hsu*, Shang-Lien Lo \\ Graduate Institute of Environmental Engineering, National Taiwan University, 71 Chou-Shan Road, Taipei, Taiwan, R.O.C.
}

Received 16 June 1998; accepted 5 October 1998

\begin{abstract}
Composting of separated pig manure (SPM) was studied in an attempt to elaborate upon organic matter (OM) transformation during the process and define parameters for product maturity using both chemical and spectroscopical methods. Composting was performed in two piles and the following parameters were measured in 10 samples during 122 days of composting: temperature, ash content, $\mathrm{C} / \mathrm{N}$ ratio, water-soluble organic $\mathrm{C}$ concentration, and humic substance content (humic acid, fulvic acid, and nonhumic fraction-HA, FA, and NHF, respectively). A spectroscopic method (Fourier-transform infrared [FTIR]) was used to study the chemical composition of the $\mathrm{OM}$. The $\mathrm{C} / \mathrm{N}$ ratio and ash content exhibited a typically high rate of change during the first 49 days and leveled off thereafter. Water-soluble organic $\mathrm{C}$ concentration rapidly increased to a maximum at Day 18 and declined thereafter. The increasing level of HA at various stages of composting indicated the progression of humification. The FTIR spectra revealed an increase in aromaticity and a decrease in carbohydrates as decomposition proceeded. Spectrometric measurements using FTIR provide information significantly correlating to conventional chemical parameters of compost maturity. (C) 1999 Elsevier Science Ltd. All rights reserved.
\end{abstract}

Keywords: Pig manure; Composting; Humic substances; Organic matter transformation; FTIR

\section{Introduction}

About 11 million heads of pigs are on feed at any time in Taiwan (Taiwan Agricultural Year Book, 1995). Approximately $80 \%$ of the feeding occurs in the country's southern six counties. Pig house manure is normally cleaned daily with groundwater down a sump where the solid fraction is separated from slurry through a mechanical sieve. Modern confinement livestock management systems generate large amounts of manure that are applied to limited land areas in proximity to the manure source. Inappropriate disposal of manure may pose environmental problems such as pollution of ground and surface waters due to leaching and run-off of organics, nutrients, and other pollutants.

Composting manure is a useful method of producing a stabilized product that can be used as a source of nutrients and soil conditioner in the field. The composted product has the advantage of improving soil structure, increasing soil organic matter (OM), suppressing soil-borne plant pathogens, and enhancing plant

\footnotetext{
* Corresponding author. E-mail: d3507001@ms.cc.ntu.edu.tw.
}

growth (Hoitink and Fahy, 1986; Chen et al., 1989). Noncomposted manure or immature compost applied to agricultural soil may cause phytotoxicity to plants and adversely affect the environment (Garcia et al., 1992).

Many tests have been proposed to assess compost maturity and stability. Changes in compost stability, or the degree to which composts have been decomposed, can be predicted with $\mathrm{C} / \mathrm{N}$ in the solid phase (Saviozzi et al., 1992; Jimenez and Garcia, 1992), soluble organic C concentration in water extracts (Garcia et al., 1991; Leita and De Nobili, 1991; Inbar et al., 1993), humification indices (Jimenez and Garcia, 1992; Chefetz et al., 1996), oxygen and $\mathrm{CO}_{2}$ respirometry (Iannotti et al., 1994), plant growth bioassays (Chen and Inbar, 1993), and NMR and IR spectroscopy (Chen and Inbar, 1993). Several authors have concluded that using a single parameter as a maturity index is insufficient and that crossbreeding several parameters is usually needed. Although several studies have investigated OM transformation using chemical and spectroscopic methods in relation to compost maturity during composting of municipal solid waste (MSW), municipal sewage sludge, 
and separated cattle manure (Chen and Inbar, 1993; Chefetz et al., 1996; Gennaro et al., 1993; Inbar et al., 1989) very few studies have been conducted on separated pig manure (SPM) compost. Since the contents, constituents, sources, and nature of the OM in SPM may be different from MSW, sewage sludge, and other animal wastes, differences in the humification and transformation of OM in SPM compost may be observed.

Understanding OM transformation throughout the composting process and proper evaluation of compost stability and maturity are essential for successful utilization of composts. The objective of this work is to study OM transformation during SPM composting using both chemical and spectroscopical methods. This research should provide information for the establishment of stability and maturity indices for composted SPM.

\section{Materials and methods}

\subsection{Composting of SPM}

The solid fraction or SPM obtained from separation of slurry was composted in two piles on an indoor concrete area at a pig farm where the pigs were fed with a typical corn/soybean ration. Fresh SPM was collected from a storage tank behind the mechanical solid-liquid separation sieve. The raw material was divided into two piles (about $1.5 \mathrm{~m}^{3}$ each) without forced aeration and composted for 122 days. The compost was turned, mixed, and sampled at $0,3,7,12,18,25,33,49,80$, and 122 days. Samples were taken immediately after turning to ensure maximum homogeneity among samples. Water was added immediately after the compost was turned to maintain a moisture content of $50-60 \%(\mathrm{w} / \mathrm{w})$. At a depth of $0.30 \mathrm{~m}$ within the composting piles, the temperature was taken daily during the first 40 days and then once every 3 days until the end of the process. The samples (4 liters) were placed in partially closed polyethylene bags, transported to the laboratory, and then stored at $5^{\circ} \mathrm{C}$. Smaller subsamples were air-dried and used for analyses.

\subsection{Chemical analyses}

The moisture content of air-dried composts was determined after drying to a constant weight at $105^{\circ} \mathrm{C}$ in a forced-air oven. Total $\mathrm{C}$ and $\mathrm{N}$ were analyzed using a Heraeus CHN-O-RAPID analyzer on composts ground to $<0.25 \mathrm{~mm}$. Ash measurements were determined at $400^{\circ} \mathrm{C}$ for $8 \mathrm{~h}$ in a furnace (NEY Model 2-525).

\subsection{Water soluble organic $C$}

Twenty grams of each compost was weighed into a 250-ml polycarbonate centrifuge tube and extracted with $200 \mathrm{ml}$ of deionized water by shaking for $24 \mathrm{~h}$. The extracts were centrifuged (Kubota Model 6800) at $10 \mathrm{~K}$ $\mathrm{rpm}$ for $25 \mathrm{~min}$ and filtered through $0.45-\mu \mathrm{m}$ filter membranes. Water extracts were immediately analyzed for $\mathrm{pH}$ and stored at $5^{\circ} \mathrm{C}$ until analysis for organic $\mathrm{C}$.

\subsection{Humic substances}

For studies on humic substances (HS), $20 \mathrm{~g}$ of compost was extracted with $200 \mathrm{ml}$ of $0.1 \mathrm{~N} \mathrm{NaOH}$ for $24 \mathrm{~h}$. Supernatant solution containing soluble HS was separated by centrifugation at $10 \mathrm{~K} \mathrm{rpm}$ and the residue resuspended in $0.1 \mathrm{~N} \mathrm{NaOH}$. This procedure was repeated eight times. The combined solutions were filtered through $0.45-\mu \mathrm{m}$ filter membranes and acidified to $\mathrm{pH} 1$ with $3 \mathrm{M} \mathrm{H}_{2} \mathrm{SO}_{4}$, allowed to stand at room temperature for $24 \mathrm{~h}$, and centrifuged to obtain the fulvic fraction (FF) (humic acid [HA] fraction discarded). The FF was separated into fulvic acid (FA) and nonhumic fraction (NHF) by adsorption of the FA onto Amberlite XAD-8 resin (mesh size 20-60, Sigma, St. Louis). The Amberlite XAD-8 resin was cleaned before use according to the method described by Thurman and Malcolm (1981). The FF was passed through the column at a flow rate of about 12 bed volumes per hour. The column was then washed by one bed volume of distilled water. At this stage, the FA adsorbed onto the resin while the NHF was eluted. The combined solutions, FF and NHF, were stored at $5^{\circ} \mathrm{C}$ until analysis for organic $\mathrm{C}$.

\subsection{Organic $C$ analyses}

Organic $\mathrm{C}$ analyses of water extracts and combined solutions, $\mathrm{FF}$ and $\mathrm{NHF}$, from $\mathrm{NaOH}$ extracts were conducted with a total organic carbon analyzer (O.I.Corporation Model 700). Organic C content in the HA fraction of $\mathrm{NaOH}$ extracts was not directly analyzed but calculated by the difference between total and FF values. The FA content was calculated as the FF minus NHF. The following humification parameters were calculated on $\mathrm{NaOH}$ extracts: (1) humification index $(\mathrm{HI})=\mathrm{HA} / \mathrm{FA}$; (2) humification ratio $(\mathrm{HR})=$ $\mathrm{HA} / \mathrm{FF}$; and (3) HA percentage $(\mathrm{HP})=100 \times \mathrm{HA} / \mathrm{HS}$.

\subsection{Fourier-transform infrared (FTIR) spectroscopy}

The FTIR spectra of SPM compost at 10 stages of the process were obtained for a wavenumber range of 4000 to $400 \mathrm{~cm}^{-1}$ in a Nicolet 550 Magna-IR spectrometer (Nicolet Instrument Corp., Madison, WI). Bulk materials were dried and finely ground. The samples were prepared for analyses by mixing $100 \mathrm{mg}$ of $\mathrm{KBr}$ with about $2.4 \mathrm{mg}$ of the material and then compressing the mixture to pellets. To obtain FTIR spectra, 400 scans were collected. Spectra of the residual ash obtained after ignition at $400^{\circ} \mathrm{C}$ for $8 \mathrm{~h}$ and loss of the 
OM were recorded using the same methodology. To compare one spectrum with another, a linear baseline correction was applied using $4000 \mathrm{~cm}^{-1}, 2000 \mathrm{~cm}^{-1}$, and $860 \mathrm{~cm}^{-1}$ as zero absorbance points. The major peaks (intensity and wavenumber) were found by using OMNIC software (Nicolet Instruments Corp.). The spectra of the ash-free OM was calculated by subtracting the spectrum of the ash from that of the bulk materials using the OMNIC software.

\subsection{Statistical analysis}

Ash content, $\mathrm{C} / \mathrm{N}$ ratio, temperature, and watersoluble organic $\mathrm{C}$ concentration results are presented as the average value of two replicates of the two composting piles, while the data for each pile is the average of three replicates. The HA, FA, and NHF content are given as the average value of three replicates of a mixed sample from the two composting piles. Spectroscopic analyses were determined on a mixed sample from the two composting piles. Results show that coefficients of variation of all chemical analyses were

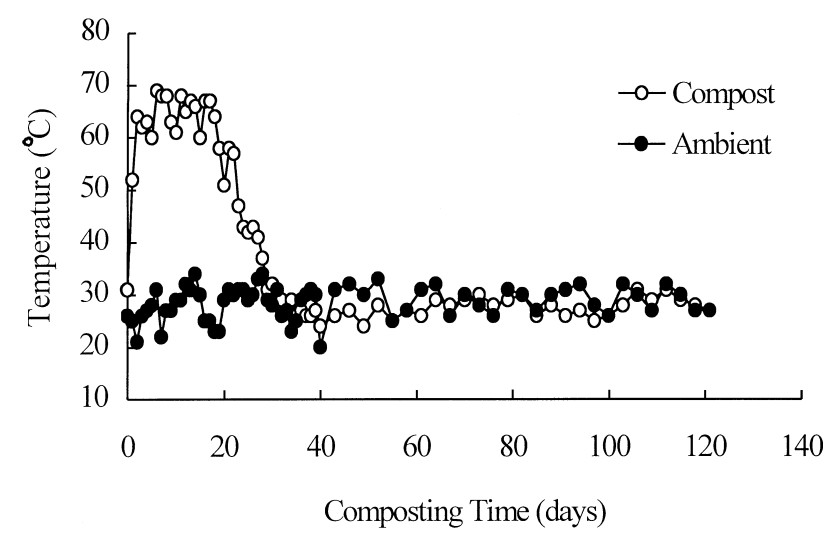

Fig. 1. Compost and ambient temperature during separated pig manure composting.

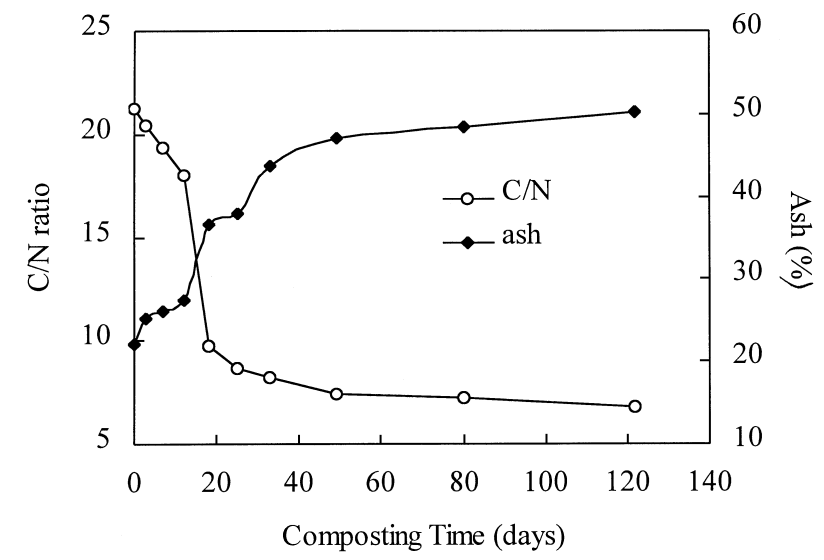

Fig. 2. The $\mathrm{C} / \mathrm{N}$ ratio and ash content during separated pig manure composting. less than 0.11 . The $t$-test result reveals that there was no significant ( $95 \%$ confidence level) difference between the two piles.

\section{Results and discussion}

\subsection{Composting of SPM}

Temperature variation during composting (Fig. 1) followed a typical pattern exhibited by many composting systems (Jimenez and Garcia, 1992; Inbar et al., 1993; Tiquia et al., 1997). Three phases were observed during the process: (1) a thermophilic phase lasting for the first 18 days, during which the temperature rose from 31 to $52^{\circ} \mathrm{C}$ within $24 \mathrm{~h}$ and increased to a maximum of $69^{\circ} \mathrm{C}$ with a mean of $64^{\circ} \mathrm{C}$; (2) a cooling phase, in which temperature began to drop at Day 18 and leveled off at Day 29; and (3) after 29 days of composting the compost temperature equaled that of the ambient with no measureable temperature changes. A temperature of $55^{\circ} \mathrm{C}$ for 3 days is necessary to destroy the pathogens in the compost, whereas the critical temperature for killing most weed seeds is $63^{\circ} \mathrm{C}$ (Rynk et al., 1992).

The change in the $\mathrm{C} / \mathrm{N}$ ratio and ash content reflects $\mathrm{OM}$ decomposition and stabilization during composting (Fig. 2). The $\mathrm{C} / \mathrm{N}$ ratio decreased rapidly from an initial value of 21 in the raw material to 10 after only 18 days. The ratio continued to decrease, but less sharply, to 7.4 after 49 days. From this point on the $\mathrm{C} / \mathrm{N}$ ratio stabilized at a value of about 7 for the remainder of the process. The initial and final ash contents of the compost were 22 and $50 \%$, respectively (Fig. 2). The change in ash content followed a reverse trend to that of the C/ $\mathrm{N}$ ratio, exhibiting three phases: (1) Days $0-18$, when most of the OM decomposed; (2) Days 18 to 49; and (3) Day 49 to the end of the experiment, during which the maturation stage began and the rate of OM decomposition was extremely low.

\subsection{Water-soluble organic $C$}

Temporal changes caused the water extract to exhibit slightly alkaline $\mathrm{pH}$ ranging from 7.35 to 7.98 . The alkaline $\mathrm{pH}$ of the water extracts throughout the composting process was probably due to the release of $\mathrm{NH}_{3}$ from the composts. The water extract from fresh SPM was yellow in color and, as composting proceeded, the intensity of this color increased to dark black at Day 18 and decreased to light brown at the end of composting. These changes in color imply changes in the type and concentration of water-soluble organics. Water-soluble organic $\mathrm{C}$ is the most readily biologically active compound in composts applied to soils. The water-soluble organic C level gradually increased from $981 \mathrm{mg}$ liter $^{-1}$ 
in the raw SPM to $1640 \mathrm{mg}$ liter $^{-1}$ at Day 12, rapidly increased to $5560 \mathrm{mg} \mathrm{liter}^{-1}$ at Day 18 , and then gradually decreased to $1020 \mathrm{mg} \mathrm{liter}^{-1}$ at the end of the process (Fig. 3). As $\mathrm{C}$ compounds that are highly available to microbes (e.g. sugars, hemicellulose, organic and amino acids, proteins) were degraded during the thermophilic stages of the decomposition, breakdown products were continuously released, resulting in an increase in water-soluble organic C. Meanwhile, dust gradually formed in the bulk samples at this stage due to microbial activity, as evidenced by dust emitted from the bulk samples during preparation. The maximum organic $\mathrm{C}$ value detected on Day 18 could be partly attributed to a release from dust, as evidenced by the highest dust level emitted from the bulk sample on that day. In the cooling and ambient temperature stages the substrate level was low and caused a reduction in soluble $\mathrm{C}$, which was accompanied by the reduction and eventual disappearance of dust in the bulk samples. Water soluble fractions of organic $\mathrm{C}$ were relatively small in the raw material $(2 \%)$ and mature compost $(4 \%)$ but were substantial at the end of the thermophilic stage (up to $17.5 \%$ ) (Fig. 3). Other investigators found similar water-soluble organic $\mathrm{C}$ trends for sludgeamended soil (Dudley et al., 1986) and composting of MSW (Iannotti et al., 1994). Leita and De Nobili (1991) and Inbar et al. (1993), however, reported that watersoluble organic $\mathrm{C}$ declined throughout the composting process for MSW and cattle manure, respectively. This suggests that the type of raw material and composting pattern greatly affect the water-soluble organic $\mathrm{C}$ concentration during composting.

A decline in water soluble organic $\mathrm{C}$ is often used as an indicator of compost maturity (Garcia et al., 1991; Saviozzi et al., 1992; Inbar et al., 1993). Organic C in the water extract of immature SPM composts consists of sugars, hemicellulose, phenolic substances, organic and amino acids, peptides, and other easily biodegrad-

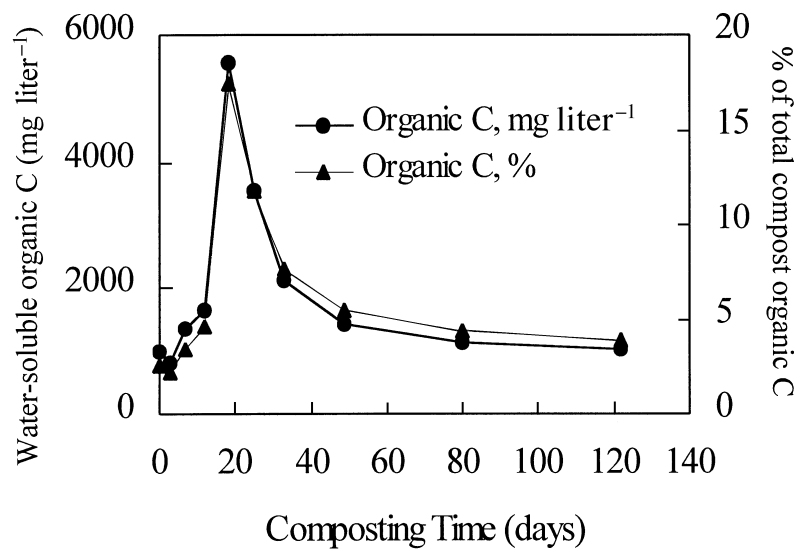

Fig. 3. Water-soluble organic $\mathrm{C}$ concentration and water-soluble organic $\mathrm{C}$ as a percentage of total compost organic $\mathrm{C}$ during separated pig manure composting. able substances (Garcia et al., 1991; Chen and Inbar, 1993). In mature compost most of the soluble organic $C$ is present as humic substances, which are resistant to further decomposition, thus explaining its increased stability observed with time during composting. Leached dissolved organics were responsible for enhanced $\mathrm{Zn}$ migration through soil columns (Boyle and Fuller, 1987). Enhancement of heavy metal solubility and mobility in soil by dissolved organic $\mathrm{C}$ after pig manure application was observed (Japenga et al., 1992).

\subsection{Humic substance content}

Humic substances comprise the most important fraction of OM because of their unique properties, such as the capacity to interact with metal ions, the ability to buffer $\mathrm{pH}$, and the ability to act as a potential source of nutrients for plants. $\mathrm{NaOH}$-extracted $\mathrm{HS}$ from composts can be separated into HA, FA, and NHF (Chen and Inbar, 1993). The levels of HA, FA, and NHF in SPM compost at various stages of the process represent the humification process (Fig. 4). Total HS increased from $28 \%$ of the OM in the raw material to $44 \%$ of the $\mathrm{OM}$ after 33 days, stabilizing at this value until the end of the process. The increasing-plateauing trend of the HS levels during SPM composting agrees with that of Inbar et al. (1989) for separated cattle manure but contradicts that reported by Chefetz et al. (1996), who showed that HS levels did not change during composting of MSW. This suggests that the type of raw material is of major importance to the humification process during composting. The FA level gradually decreased from $7.7 \%$ of the $\mathrm{OM}$ in the raw material to $6.3 \%$ in the mature compost with a peak value of $8.6 \%$ occurring at Day 18. The HA level increased during the composting process, gradually increasing from 4.6 to $6.0 \%$ for the first 18 days, sharply increasing to $15 \%$ at Day 25 , and then gradually increasing to $21 \%$ in the mature compost. The increasing level of HA represents the degree of humification and maturity of compost. In general, fresh composts contain low levels of HA and higher levels of FA (Inbar et al., 1989; Ciavatta et al., 1993; Chefetz et al., 1996), a trend also shown in this study. As composting proceeded the HA content increased, whereas the FA level slightly decreased. Of the humic substances extracted with $\mathrm{NaOH}$, the majority (4364\%) was recovered as NHF for the first 49 days and shifted to HA for the remainder of the process. Temporal changes of NHF exhibited a trend similar to that of water-soluble organic C. The NHF increased rapidly from 16 to $25 \%$ of the OM for the first 18 days of composting, probably due to a continuous release of breakdown products of the easily biodegradable substances during the thermophilic stage, and then decreased to $19 \%$ in the mature compost due to decomposition and humification of the breakdown 


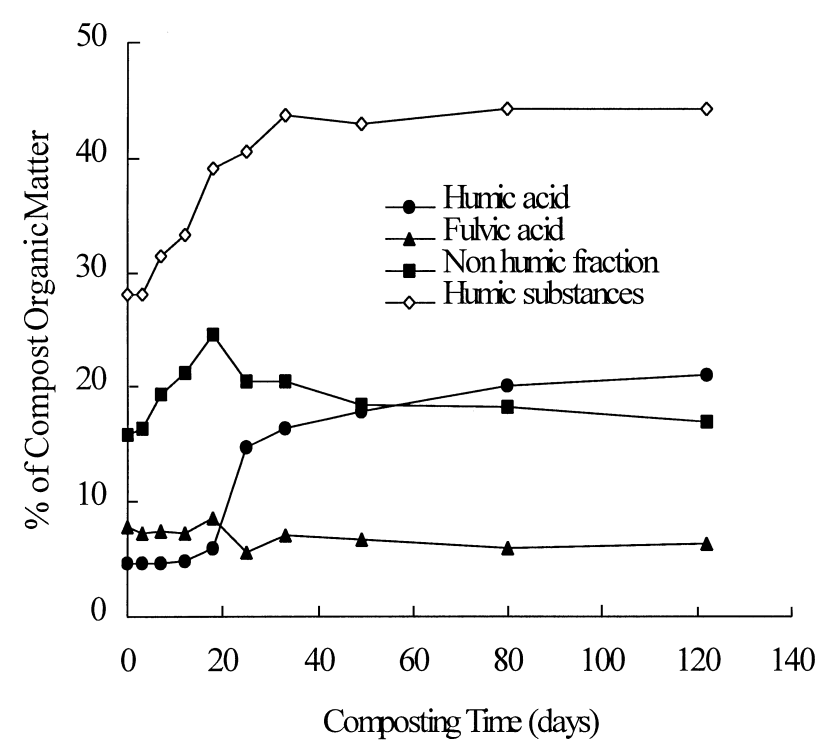

Fig. 4. Relative content of humic acid, fulvic acid, nonhumic fraction, and humic substances as a percentage of compost organic matter during separated pig manure composting.

products and not-easily biodegradable OM during the cooling and ambient temperature stages. All three humification parameters (HI, HR, HP) increased during the composting as follows (Table 1): (1) HI remained steady at $0.6-0.7$ for the first 18 days, sharply increased to 2.63 at Day 25 , and slowly increased to a final value of 3.33 ; (2) HR remained steady at $0.17-0.20$ for the first 18 days, sharply increased to 0.56 at Day 25, and increased to 0.90 in the mature compost; and (3) HP values exhibited a similar trend to those exhibited by HI and HR. The increasing trend of these parameters indicates that HA became the main fraction of HS during composting. The trend of change of these values is similar in various wastes although specific values differ in other wastes. HI and HR are commonly used to analyze the humic fraction (Jimenez and Garcia, 1992; He et al., 1995; Chefetz et al., 1996). The changes in HI, $\mathrm{HR}$, and HP values reveal that the FA and NHF extracted from SPM contain relatively high levels of

Table 1

Humification index (HI), humification ratio (HR), and percentage of humic acid (HP) during separated pig manure composting

\begin{tabular}{lccc}
\hline Composting time (days) & HI & HR & HP \\
\hline 0 & 0.60 & 0.20 & 16.4 \\
3 & 0.63 & 0.19 & 16.3 \\
7 & 0.63 & 0.18 & 14.9 \\
12 & 0.66 & 0.17 & 14.3 \\
18 & 0.69 & 0.18 & 15.3 \\
25 & 2.63 & 0.56 & 36.1 \\
33 & 2.34 & 0.60 & 37.4 \\
49 & 2.69 & 0.71 & 41.5 \\
80 & 3.38 & 0.83 & 45.4 \\
122 & 3.33 & 0.90 & 47.4 \\
\hline
\end{tabular}

biodegradable OM that was mostly decomposed during Days 18-25.

\subsection{FTIR spectroscopy}

The FTIR spectra of all six bulk SPM compost samples from different stages (raw, 7, 18, 33, 80, and 122 days) of composting exhibited similar peaks (Fig. 5). The main absorbance bands were a broad band around $3300-3400 \mathrm{~cm}^{-1}$ (H bonds, OH groups), two distinct peaks at 2930 and $2850 \mathrm{~cm}^{-1}(\mathrm{C}-\mathrm{H}$ asymmetric, $\mathrm{C}-\mathrm{H}$ stretch of $-\mathrm{CH}$ ), a well-pronounced peak at $1650 \mathrm{~cm}^{-1}$ $(\mathrm{C}=\mathrm{C}$ in aromatic structure), a small peak at 1560 $\mathrm{cm}^{-1}$ (amide II bonds), a shoulder at $1420 \mathrm{~cm}^{-1}$ (C-H deformation of $\mathrm{CH}_{2}$ or $\mathrm{CH}_{3}$ groups), a rising narrow sharp peak at $1385 \mathrm{~cm}^{-1}\left(\mathrm{COO}^{-}, \mathrm{CH}_{3}\right)$, a small peak at $1250 \mathrm{~cm}^{-1}$ (aromatic C, C-O stretch), a slight shoulder around $1160 \mathrm{~cm}^{-1}$ (aliphatic $\mathrm{CH}_{2}, \mathrm{OH}$ or $\mathrm{C}-\mathrm{O}$ stretch of various groups) and a broad peak at 1080 to $1040 \mathrm{~cm}^{-1}$ (C-O stretch of polysaccharide, Si-O stretch) (Baes and Bloom, 1989; Inbar et al., 1989).

Distinct changes in the spectra resulting from the composting process were reduction of peaks in the aliphatic region at 2930 and $2850 \mathrm{~cm}^{-1}$. The $1560-\mathrm{cm}^{-1}$ peak became a shoulder possibly as a result of the relatively rapid biodegradation of the amino chain. Peaks in the polysaccharide region at $1050 \mathrm{~cm}^{-1}$ decreased, while the $1380 \mathrm{~cm}^{-1}$ peak became sharper. The relative height of the aromatic region at $1650 \mathrm{~cm}^{-1}$ rose as the composting process proceeded. Most peaks in the aliphatic, amino, and polysaccharide regions leveled off during composting, indicating that SPM

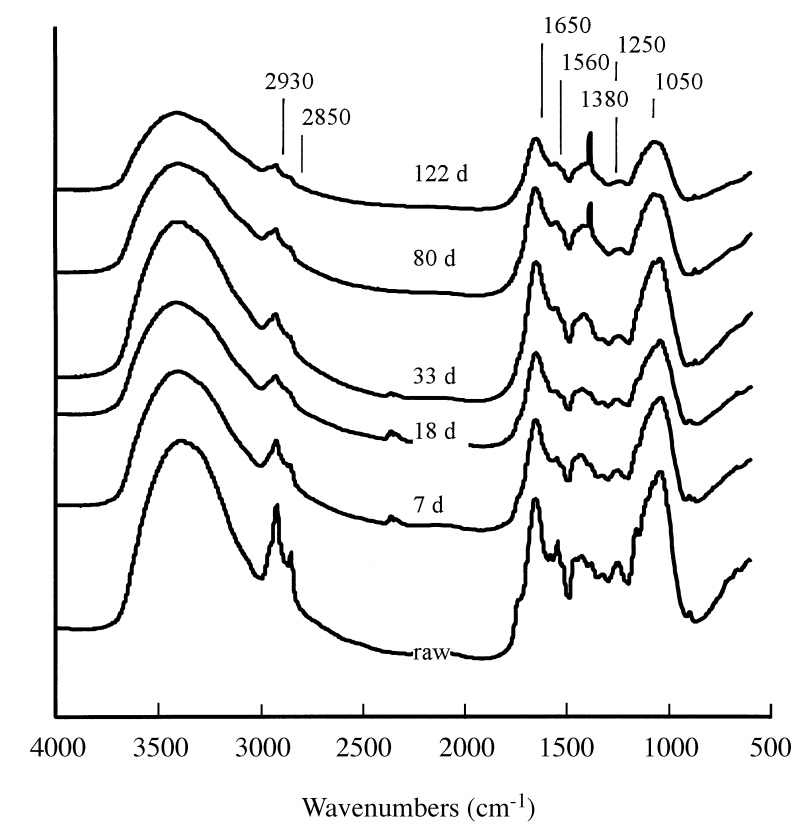

Fig. 5. Fourier-transform infrared spectra of bulk separated pig manure compost at six stages of composting (raw, 7, 18, 33, 80, 122 days). 
material had become more uniform and stable at the end of the process.

In general, the spectra of the bulk SPM resemble spectra of composted separated cattle manure (Inbar et al., 1989) and soil HAs classified as Type III (Mud Lake HA) by Stevenson and Goh (1971). Samples of separated cattle manure and this type of soil HAs are distinguished by the presence of a strong absorption band near $1650 \mathrm{~cm}^{-1}$, moderately strong absorption at $1540 \mathrm{~cm}^{-1}$, strong absorption near $1050 \mathrm{~cm}^{-1}$, and relatively pronounced absorption near $2900 \mathrm{~cm}^{-1}$. A unique feature of these spectra is the presence of bands indicative of proteins and carbohydrates.

The spectra of SPM compost (wavenumbers 4000$400 \mathrm{~cm}^{-1}$ ) were different from spectra of hardwood bark, pine bark, winery solid waste, and MSW composts (Inbar et al., 1991; Niemeyer et al., 1992; Chefetz et al., 1996). The main differences between the spectra of SPM compost and those of other composts were the following: (1) the aromatic and polysaccharide peaks had become the main peak in the spectra of SPM, bark, and winery waste composts as opposed to the $1450 \mathrm{~cm}^{-1}$ peak in the MSW spectra; (2) a narrow sharp peak at $1800 \mathrm{~cm}^{-1}$ in MSW spectra that appears as a small peak at 1710 to $1720 \mathrm{~cm}^{-1}$ in bark and winery waste compost spectra, does not appear in the SPM spectra; (3) a sharp peak at $2520 \mathrm{~cm}^{-1}$, which can be attributed to $\mathrm{S}-\mathrm{H}$ stretch of aromatic or nonaromatic mercaptans and sulfides in the MSW spectra, does not appear in the SPM spectra; and (4) an intense and sharp peak at $870 \mathrm{~cm}^{-1}$ in the MSW spectra that does not appear in spectra of SPM and other compost.

Following Inbar et al. (1989), changes in the SPM spectra were monitored by calculation of the ratio

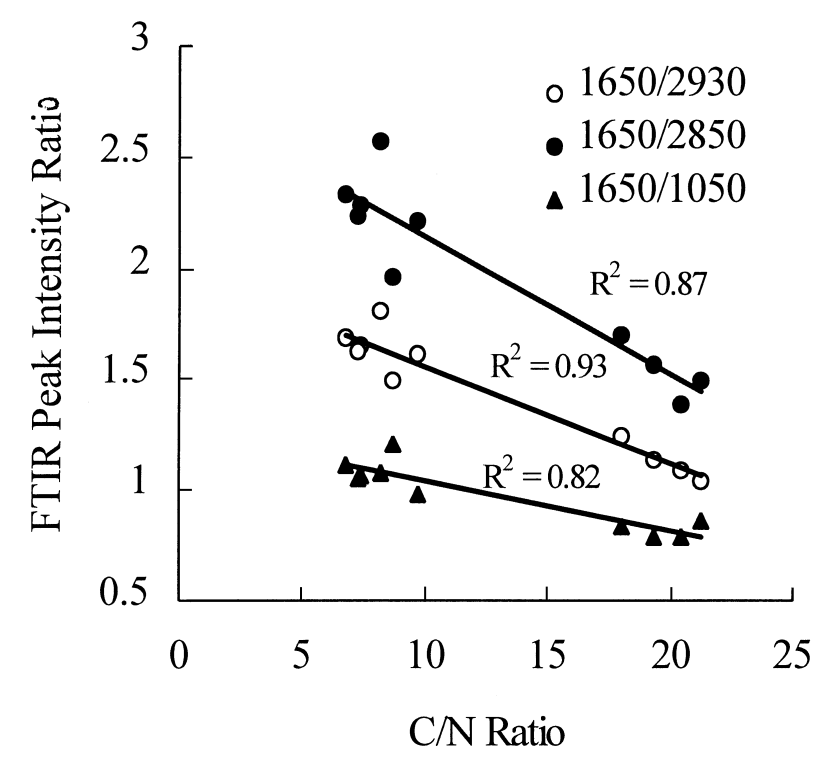

Fig. 6. Fourier-transform infrared (FTIR) peak intensity ratios (1650/ $2930,1650 / 2850,1650 / 1050 \mathrm{~cm}^{-1}$ ) versus $\mathrm{C} / \mathrm{N}$ ratio during separated pig manure composting. between the intensity of major peaks. The peaks at 2930, 2850, 1650, 1560, and $1050 \mathrm{~cm}^{-1}$ were chosen for these calculations. The $1650 / 2930$ ratio (aromatic $\mathrm{C} /$ aliphatic C) increased from 1.04 to 1.68 , the $1650 / 2850$ ratio (aromatic $\mathrm{C} /$ aliphatic $\mathrm{C}$ ) increased from 1.49 to 2.33 , the $1650 / 1560$ ratio (aromatic C/amide II bond) increased from 1.36 to 1.67 , and the $1650 / 1050$ ratio (aromatic $\mathrm{C} /$ polysaccharide) increased from 0.86 to 1.11 . The changes in these ratios indicate that easily degradable OM constituents, such as aliphatic and amide components, polysaccharides, and alcohols, are chemically or biologically oxidized and, therefore, the mature compost contained more aromatic structures of higher stability. The linear correlation of the aromatic to aliphatic peak ratios (1650/ 2930 and 1650/2850) and aromatic to polysaccharides peak ratio (1650/1050) to the $\mathrm{C} / \mathrm{N}$ ratio (Fig. 6) exhibited $R^{2}=0.93,0.87$, and 0.82 , respectively. This correlation indicates that FTIR is a useful and reliable tool in the analysis of OM decomposition during composting.

Spectra of residual ash samples were recorded to verify whether these peaks were related to OM or mineral forms in the compost. The residual ash spectra were similar to that of calcite $\left(\mathrm{CaCO}_{3}\right)$, exhibiting major absorption bands at 2350, 2210, 1620, 1430, and $874 \mathrm{~cm}^{-1}$. The ash also exhibited peaks in the 1100 to $950 \mathrm{~cm}^{-1}$ region that can be attributed to Si-O components (Kodama, 1985). Thus, mineral matter is responsible for the unusual peaks observed in the spectra of the SPM compost.

To correct and reduce the effects of mineral components, the residual ash spectrum was subtracted from the bulk spectrum. The spectra of the ash-free SPM compost at three stages (raw, 33, 122 days) of composting are presented in Fig. 7. The spectrum of the mature compost is generally similar to that of the ash-free

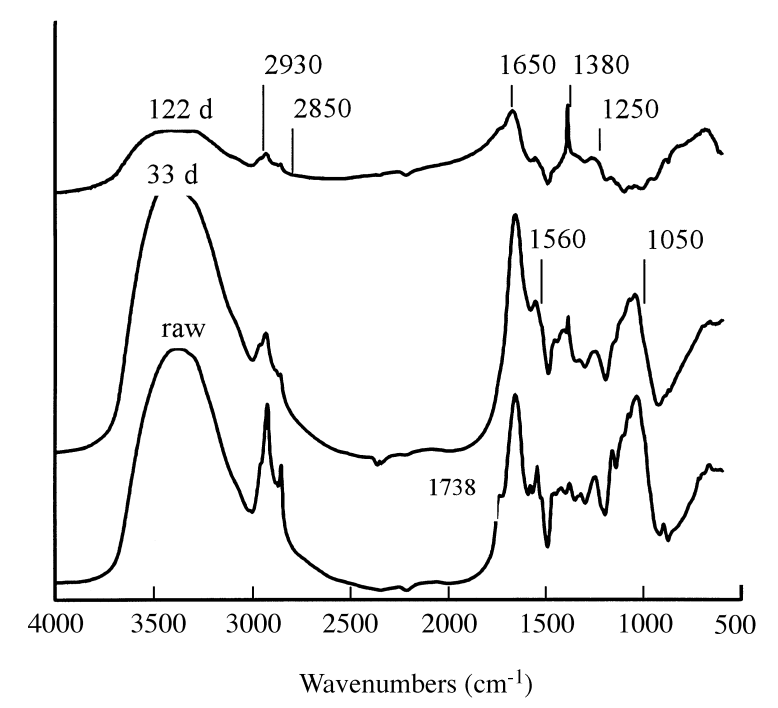

Fig. 7. Fourier-transform infrared spectra of ash-free organic matter in separated pig manure compost at three stages of composting (raw, 33, 122 days). Ash spectra were subtracted from those of the bulk materials. 
MSW compost (Chefetz et al., 1996) with specific differences in (1) the polysaccharide region peak (1050 $\mathrm{cm}^{-1}$ ), which could be attributed to the ash residual leveling off in SPM while remaining broad in MSW compost; and (2) the 1385 peak, which was prominent in the SPM spectra but small in MSW compost spectra. Other differences between the raw SPM materials and mature compost as revealed by comparing the subtracted spectra can be pointed out: (1) leveling off in the aliphatic region (2930 and $2850 \mathrm{~cm}^{-1}$ ); (2) reduction of the $1738-\mathrm{cm}^{-1}$ shoulder $\left(\mathrm{CO}_{2} \mathrm{H}\right.$ groups $)$ in the mature compost; (3) a relative increase in the aromatic region $\left(1650 \mathrm{~cm}^{-1}\right)$; (4) reduction and formation of a shoulder of the $1540-\mathrm{cm}^{-1}$ peak (amide II bond); (5) a sharp increase in the $1380-\mathrm{cm}^{-1}$ peak $\left(\mathrm{COO}^{-}, \mathrm{CH}_{3}\right)$; and (6) leveling off in the polysaccharide region $\left(1050 \mathrm{~cm}^{-1}\right)$. The leveling off of the polysaccharide region peak $\left(1050 \mathrm{~cm}^{-1}\right)$ in the ash-free mature SPM compost indicates that the broad $1050-\mathrm{cm}^{-1}$ peak in the bulk mature compost was attributed to $\mathrm{Si}-\mathrm{O}$ components.

\section{Conclusions}

Decomposition of SPM was characterized using various chemical methods. The $\mathrm{C} / \mathrm{N}$ ratio, ash content, and HS content, along with temperature, changed rapidly during the first 30 days and reached a plateau thereafter. In addition, the amount of water-soluble organic $\mathrm{C}$ was substantial at the end of the thermophilic stage. These parameters were all good indicators of SPM compost stability and maturity. FTIR spectroscopy was also applied to bulk SPM compost samples without extraction. The findings in FTIR spectra in this research indicate that easily degradable OM constituents, such as aliphatic chains, polysaccharides, alcohols, and protein, are decomposed and, therefore, the mature compost contained more aromatic structures of higher stability. OM transformation, as analyzed by FTIR, also suggests that the composting process transforms heterogeneous raw SPM OM to a compositionally uniform product at the end of the process. The high correlation between the 1650/ $2930,1650 / 2850$, and 1650/1050 FTIR peak ratios and $\mathrm{C} / \mathrm{N}$ ratio indicate that these ratios can be used as maturity indices. All chemical and spectroscopic parameters exhibited three phases: (1) rapid decomposition during the first 30 days; (2) stabilization until Day 50; and (3) maturation from Day 50 on. The SPM compost, described in this study was mature and ready for use as an agricultural substrate after about 80 days of composting.

\section{Acknowledgement}

Acknowledgement is made to the Taiwan Sugar Corporation for its support of this research.

\section{References}

Baes, A.U., Bloom, P.R., 1989. Diffuse reflectance and transmission fourier transform infrared (DRIFT) spectroscopy of humic and fulvic acids. Soil Science Society of America Journal 53, 695-700.

Boyle, M., Fuller, W.H., 1987. Effect of municipal solid waste leachate composition on zinc migration through soils. Journal of Environmental Quality 16, 357-360.

Chefetz, B., Hatcher, P.G., Hadar, Y., Chen, Y., 1996. Chemical and biological characterization of organic matter during composting of municipal solid waste. Journal of Environmental Quality 25, 776-785.

Chen, Y., Inbar, Y., 1993. Chemical and spectroscopic analysis of organic matter transformations during composting in relation to compost maturity. In: Hoitink, H.A.J., Keener, H.M. (Eds.), Science and Engineering of Composting: Design, Environmental, Microbiological and Utilization Aspects. Renaissance, Worthington, OH, pp. 551-600.

Chen, Y., Inbar, Y., Hadar, Y., Malcolm, R.L., 1989. Chemical properties and solid-state CPMAS ${ }^{13} \mathrm{C}-\mathrm{NMR}$ of composted organic matter. Science of the Total Environment 81/82, 201-208.

Ciavatta, C., Govi, M., Pasotti, L., Sequi, P., 1993. Changes in organic matter during stabilization of compost from municipal solid waste. Bioresource Technology 43, 141-145.

Dudley, L.M., McNeal, B.L., Baham, J.E., 1986. Time-dependent changes in soluble organics, copper, nickel, and zinc from sludge amended soils. Journal of Environmental Quality 15, 188-192.

Garcia, C., Hernandez, T., Costa, F., 1991. Changes in carbon fractions during composting and maturation of organic wastes. Environmental Management 15, 433-439.

Garcia, C., Hernandez, T., Costa, F., Pascual, J.A., 1992. Phytotoxicity due to the agricultural use of urban wastes. Germination experiments. Journal of the Science of Food and Agriculture 59, 313-319.

Gennaro, M.C., Ferrara, E., Abollino, O., Vanni, A., Petronio, B.M., Petruzzelli, G., Liberatori, A., 1993. Multi-method analysis in studies of characterization and degradation of municipal treatment sludges. International Journal of Environmental Analytical Chemistry $53,101-114$.

He, X.T., Logan, T.J., Traina, S.J., 1995. Physical and chemical characteristics of selected U. S. municipal solid waste composts. Journal of Environmental Quality 24, 543-552.

Hoitink, H.A.J., Fahy, P.C., 1986. Basis for the control of soilborne plant pathogens with composts. Ann. Rev. Phytopathol. 24, 93-114.

Iannotti, D.A., Grebus, M.E., Toth, B.L., Madden, L.V., Hoitink, H.A.J., 1994. Oxygen respirometry to assess stability and maturity of composted municipal solid waste. Journal of Environmental Quality 23, 1177-1183.

Inbar, Y., Chen, Y., Hadar, Y., 1989. Solid state carbon-13 nuclear magnetic resonance and infrared spectroscopy of composted organic matter. Soil Science Society of America Journal 53, 1695-1701.

Inbar, Y., Chen, Y., Hadar, Y., 1991. Carbon-13 CPMAS NMR and FTIR spectroscopic analysis of organic matter transformations during composting of solid wastes from wineries. Soil Science 152, 272-282.

Inbar, Y., Hadar, Y., Chen, Y., 1993. Recycling of cattle manure: the composting process and characterization of maturity. Journal of Environmental Quality 22, 857-863.

Japenga, J., Dalenberg, J.W., Wiersma, D., Scheltens, S.D., Hesterberg, D., Salomons, W., 1992. Effect of liquid animal manure application on the solubilization of heavy metals from soil. International Journal of Environmental Analytical Chemistry 46, 25-39.

Jimenez, E.I., Garcia, V.P., 1992. Determination of maturity indices for city refuse composts. Agriculture Ecosystems \& Environment 38, 331-343.

Kodama, H. (Ed.), 1985. Infrared spectra of minerals, reference guide to identification and characterization of minerals for the study of soils. Ministery of Supply and Services Canada, Ottawa, Canada. 
Leita, L., De Nobili, M., 1991. Water-soluble fractions of heavy metals during composting of municipal solid waste. Journal of Environmental Quality 20, 73-78.

Niemeyer, J., Chen, Y., Bollag, J.M., 1992. Characterization of humicacids, compost, and peat by diffuse reflectance fourier-transform infrared spectroscopy. Soil Science Society of America Journal 56, 135-140.

Rynk, R., van de Kamp, M., Willson, G.B., Singley, M.E., Richard, T.L., Kolega, J.J., Gouin, F.R., Laliberty Jr., L., Kay, D., Murphy, D.W., Hoitink, H.A.J., Brinton, W.F., 1992. On farm composting. Northeast Regional Agriculture and Engineering Service, Ithaca.
Saviozzi, A., Levi-Minzi, R., Riffaldi, R., Benetti, A., 1992. Evaluating garbage compost. BioCycle 33, 72-75.

Stevenson, F. J., Goh, K.M., 1971. Infrared spectra of humic acids and related substances. Geochimica et Cosmochimica Acta 35, 471-483.

Taiwan Agricultural Year Book, 1995. Department of Agriculture and Forestry, Taiwan Provincial Government, Taiwan.

Thurman, E.M., Malcolm, R., 1981. Preparative isolation of aquatic humic substances. Environmental Science and Technology 15, 463466.

Tiquia, S.M., Tam, N.F.Y., Hodgkiss, I.J., 1997. Composting of spent pig litter at different seasonal temperatures in subtropical climate. Environmental Pollution 98(1), 97-104. 